\title{
Human Capital for Quality Infrastructure Development in South Africa: A Project-Based Pedagogical Analysis
}

\author{
*Bongani Reginald Qwabe, Fayth Ruffin \\ University of KwaZulu Natal, South Africa \\ *qwabeb@ukzn.ac.za
}

\begin{abstract}
Traditional/skills-based teaching doesn't meet the demands of our $21^{\text {st }}$ century" -Garelick, 2012. The widespread effects of globalisation and new technologies demand rethinking of knowledge creation and labour force preparedness for $21^{\text {st }}$ century development. The rise of a knowledge-based economy and information society requires public managers with human capital sufficient to fulfil developmental challenges. The demand for quality infrastructure in South Africa exceeds existing proficiency of human capital. The $21^{\text {st }}$ century and South Africa's post 1994 challenges including infrastructure development demand a new generation of public managers and administrators equipped with acuity and negotiation outlooks, communication and problem-solving skills, research and analytical abilities, and cognitive capacity enabling them to promote, influence, and monitor project development and management in a substantially globalized world. From a pedagogical standpoint, while knowledge creation and innovative teaching strategies are arguably drivers of a labour force that meet challenge of development, the authors of this conceptual analytical article contend that traditional approaches of teaching project management in South African higher education institutions (HEIs) fail to adequately prepare students to manage 'real-world projects' that foster growth and development. Rather, projectbased learning (PjBL) offers a strategic way forward to fill project management skills gap and project management knowledge deficit in the public sector, which should be subject to the recommended research agenda.
\end{abstract}

Key words: globalisation, knowledge-based economy, information society, infrastructure development and human capital development

\section{Introduction}

Rapid change and the growth of technology resulting from globalisation during the $21^{\text {st }}$ century have complicated the management and the delivery of projects particularly in the public sector. Globalization has been subject to a multitude of definitions including interconnectedness of world affairs through cross-border flow of communications technology, knowledge, people, values and ideas (Altbach \& Knight, 2007). Globalization is likewise said to be latest stage in a long accumulation of technological advance be it commercial, financial, religious, cultural, social, political or otherwise (Langhorne, 2001). Across definitions of globalization, it is agreed that information communication technology (ICT) has accelerated the speed of production, use and distribution of a knowledge economy indicative of an information society in a global era (Okoli, 2012). Just as there are many definitions of globalization so are there multiple forms of globalization such as economic, political, social, cultural, and environmental as well as others (Bottery, 2006). Irrespective of the definition or form of globalization, ICT is a central component and proficient human capital is necessary to sustain it. According to human capital theory, to educate a population is to invest in capital for increased production and said investment is just as worthwhile as one in physical capital like land, factor and equipment instrumental to an industrializing society (Woodhall, 1997). While business value was once primarily based upon capital equipment, some economists now believe that human capital ultimately increases the economic development of a nation and education produces the human capital needed. For Okoli (2012) the new human capital theory focuses on microeconomics, which stresses a highly skilled and flexible work force to ensure national success within the new global knowledge economy.

ICT or Information Technology (IT) developments have resulted to a new landscape in which human capital must be able to operate organisations in a way that readily ascertains and applies knowledge for project management. Matavire, Chigona, Roode \& Sewchurran (2010) affirm that IT knowledge constitutes the most important factor in delivery of projects. Worldviews associated with modernity and lecturer centered, positivist-oriented, content based pedagogy were prevalent and perhaps once useful in 
an industrial sing society preoccupied with a division of labor that maximized profit. However, contemporary concerns with human rights and prosperity for all nations, worldviews associated with post-modernism or post-structuralism aligned with student-centered, social-constructivist-oriented PjBL pedagogy seem consistent with a knowledge-based economy and information society.In this regard, this article is based on social constructivist theory, with project-based learning (PjBL) supported as the pedagogical method in public administration and management curriculum. While research reveals that PjBL results in students being more innately motivated, inclined to show conceptual understanding, and well-adjusted than students in traditional education modes, this article contends that there is insufficient research to explore the link between what PjBL pedagogy offers on the one hand and what public service requires of professional project managers on the other hand. To help understand the significance of $\mathrm{PjBL}$ to workplace preparedness, the article further provides an analysis of project management and successes and failures from a South African public sector context. Such failures reaffirm the need for empirical research into the role of PjBL in the development of project leadership and professionals capable of managing public projects in the context of development in the post 1994 era. The article concludes with a recommended research agenda.

\section{Literature Review}

Project management and Project-Based Learning (PjBL): Creating $21^{\text {st }}$ century public sector professionals: For over decades now there has been a growing realization that the traditional education system does not adequately prepare students with competencies and skills necessary to adapt and thrive in the global economy. Chen cited in Baron and Darling-Hammond (2008) argues that it is unfortunate that the current education system remains caught in a web of education thinking and system that originated a century ago. Panasan \& Naungchalerm (2010) contend that the use of content-based and traditional pedagogical approaches for the development of effective organizations in the knowledge era should be phased out. Similarly, Baron et al. (2008) allege that students should be engaged in an authentic learning process with projects and activities that require them to employ subject knowledge to solve realworld challenges. This approach to learning places the learner at the hub of the learning process where students pursue solutions to nontrivial problems by asking and refining questions, debating ideas, making predictions, gathering and analysing data (Blumefeld, Soloway, Marx, Krajcik, Guzdial, \& Palincsar, 1991). PjBL does not follow a particular content-based teaching plan or a fixed structure of learning although overarching objectives and outcomes are established. In PjBL the project is the core of the interdisciplinary teaching strategy. Students grapple with and learn the central concepts of a discipline and how it interacts with other disciplines by way of project/s (Thomas, 2000). This encourages innovation in learning and application of newly acquired knowledge.

It is undisputed that the $21^{\text {st }}$ century has seen a dramatic up-swing in the demand for project management skills and competencies in the public sector. Project management is central to service delivery. Vagelatos, Tsaknakis, Foskolos \& Komninos (2010) argue that e-government has emerged as the means by which government can participate in the knowledge-based economy and information society as a means to improve service delivery. The demand for new knowledge has in turn raised perpetual demand for human capital development (Paavola \& Hakkarainen, 2005). Resulting in part from globalization, knowledge-intense work such as implementation of infrastructure is contingent to the use of high technology. Hence, the workforce must supply project management professionals with sufficient competencies and innovative approaches for successful project implementation in both public and private sector. Public sector organisations in the knowledge-based economy and information society require a new generation of public managers and administrators equipped with acuity and negotiation outlook, communication and problem-solving skills, research and analytical skills and cognitive capacity enabling them to promote, influence, and monitor project development and management in a substantially globalised world (Paavola et al., 2005).

Critical independent thinking and high level negotiation and communication skills do not result from positivist-oriented, lecturer-centred, and content-based teaching and learning. Rather, social constructivist-oriented curriculum that is student-centred and driven by projects and problems is consistent with skill sets required for project management. Panasan et al., (2010) assert that students need to acquire scientific knowledge to be fully prepared to manage 'real-world projects' that foster development. As such, students should be exposed to 'real-world' projects during the learning process. Bell (2010) argues that 'real-world' projects augment learning for students. In this regard, contemporary pedagogical models should be designed in a manner that creates project practitioners with high level 
analytical capabilities particularly in a developmental state like South Africa. To advance project management skills this conceptual analytical article lays the foundation for empirically exploring the extent to which several African countries have adopted PjBL in public sector higher education curriculum, particularly in disciplines of public administration, engineering and ICT and the extent to which public service officials desire students shaped by PjBL. From a project management standpoint, PjBL is considered an alternative approach and an innovative learning model that organises knowledge enquiry around 'real-world projects' and places students in a realistic project environment (Blumefeld et al., 1991).Thomas as cited in Gülbahar \& Tinmaz (2006) lists five major criteria for a method of learning to be classified as PjBL. In his classification he argues that PjBL projects:

- Are central to the learning curriculum.

- Are focusing around a specific question(s) or problem(s) from which students will learn the principles of a discipline.

- Engage students in a constructive investigation.

- Are student-driven.

- Reflect real-life situations.

Boondee, Kidrakarn \& Sa-Ngiamvibool (2011) argue that PjBL approach increases motivation and promotes cooperative learning. As a result, students develop and improve their project competencies and skills through real participation in projects. These include project site visits together with in-class and research-oriented assessments simulate duties and responsibilities of real-world project managers, which allow students to not only, learn by doing but to learn with an eye toward innovation.

Learning and innovation: A theoretical perspective: Learning and innovation are arguably key components of a knowledge-based economy and information society. Yet the environment for learning and innovation is only as effective as the infrastructure that sustains it. Vagelatos et al., (2010) posit that the ongoing modernization of public administration functions can only be realized through complex and technology intensive projects. The use of Information and Technology (IT) in project management demands capacity building among project officials such as new project management knowledge. Paavola et al., (2005) contend that the epistemology related to learning and knowledge is becoming increasingly significant in the 21st century. The authors further argue that knowledge and related concepts, such as expertise and intelligence, are continuing to delineate activities in the knowledge-based society. Similarly, Stutt and Motta cited in Paavola et al. (2005) argue that there is a continued trend in the 'epistemification' resulting from the sophisticated and knowledge-laden activities which demands a diverse range of project management related skills such as such as analytical, communication and problem-solving skills. These scholars in effect raise a pedagogical question 'how to teach more effectively?' With this question in mind, constructivist approaches as noted by Gülbahar et al., (2006) have gained prominence for several reasons including its learner-centred approach and active participation of students. As emphasised in this article, the constructivist learning and knowledge creation is consistent with PjBL model. According to Doppelt cited in Gülbahar et al. (2006) PjBL is one of the methods grounded in social constructivism where experiential activities engage students in construct knowledge while applying management skills to projects. The role of the instructor as described by Frank, Lavy \& Elata (2003) in a PjBL is to help learners to construct their own knowledge based on a real-world setting. Thus, PjBL leans on real-life projects such that students are more likely to internalise knowledge. Savin-Baden \& Major as cited in Kemp (n.d., p. 46) write:

"The social constructivist model is based in theories of social constructivism; in which learners construct knowledge through discourse with other members of the community, including the tutor. Learning is produced by the team, and not reproduced from disciplinary authority."

To reiterate the assertion, several scholars maintain that learning is an activity that is individual-based and allows learners to construct their own personal mental model of the real world and reconstruct their own reality based on their life experiences. As such, constructivist assessments from which learners continually update and construct their own interpretation of the world must also be individualized and induce students to construct knowledge independently (Prince \& Felder, 2006; Dabbagh, 2003). This is contrary to positivism where the learners are passive recipients of knowledge given to them by the instructor (Prince et al., 2006). Through PjBL and social constructivism, as opposed to the traditional lecture-based teaching method and positivism, students are encouraged to be innovative when engaging and solving real-life problems and designing and managing real-world projects.. In a globalized world, argues Kars (2009) organisations must constantly adjust to new ways of conducting their business. 
According to Kars (2009) new implies the "generation, acceptance and implementation of new ideas, processes, product and services". Therefore, the construction of new knowledge connotes the importance of learning and innovation for organisational development. A conceptual framework for the innovation and learning approach is depicted in Figure 1

\section{Figure 1: Innovation and Learning Approach} Enablers

\section{Results}

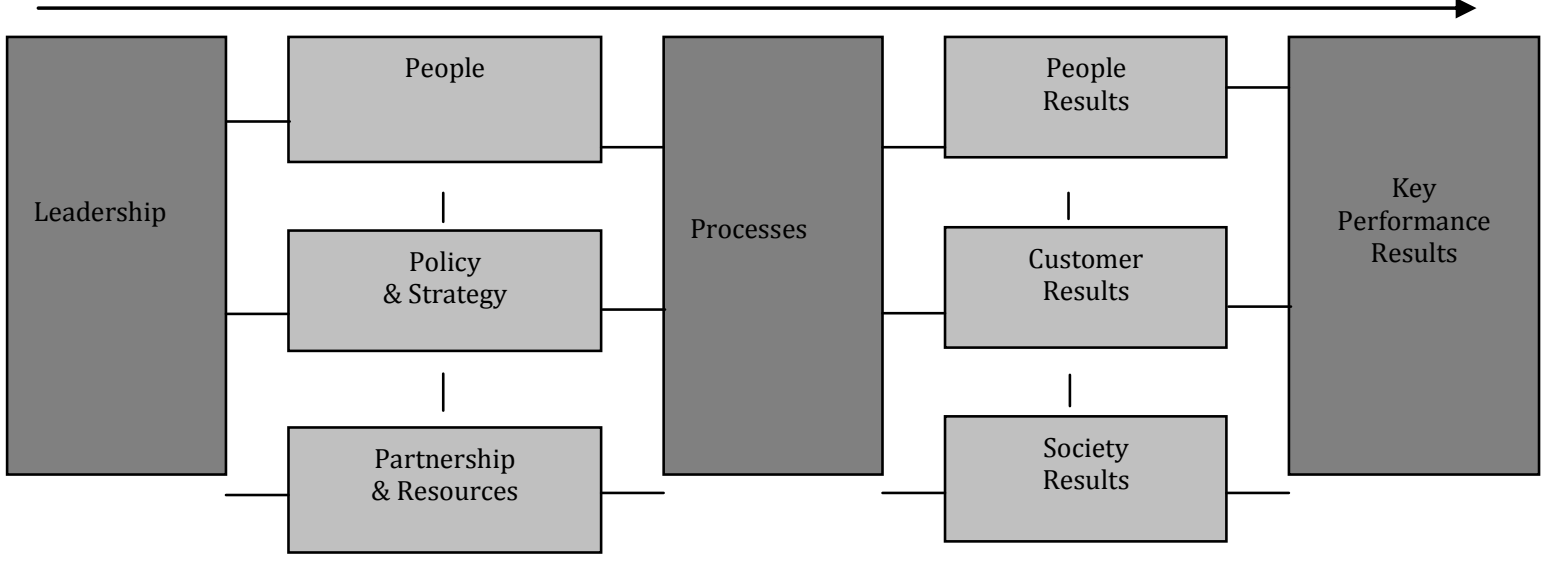

Adapted from the European Foundation for Quality Management (EFQM) 1999

Innovation and learning in the $21^{\text {st }}$ century should enable enhancement of key performance results in a developmental environment. This includes enabling leadership and building capacity to mobilise partnerships while formulating and implementing policy and strategies. Toward this end, PjBL simulates practical experiences in class and through assessment that develop human capital aimed at managing projects for desired results. Innovation and learning are critical elements in knowledge development, which in turn should equip organizations to achieve and improve organizational performance. Reynolds (2009) contends that contemporary learning abilities (CLAs) should be transferable and applicable towards constructive work context that the learners will encounter in the future. Therefore, the learning process should afford the learners an opportunity to engage with real-life projects in the learning process.

\section{Methodology}

The methodology for this pedagogical analysis of project-based teaching and learning and its relationship to human development for technologically advanced project management include three components.

- Detailed literature review on PjBL from a theoretical standpoint.

- Detailed literature review that disclosed successful and unsuccessful project management in South Africa and other countries.

- Identification of a theoretical framework that reflects relationships between variables to be tested, which is provided in Figure 1.

South African government publications and scholarly journals sourced from Google Scholar, Ebscohost, Science Direct, JSTOR and other search engines were consulted for the literature review section as well as the section on results and discussion.

\section{Results and Discussion}

South Africa's transition into democracy marked a significant period in the lives of people. It further brought a notion of 'development-state' into reality. As such, the Constitution of the Republic succinctly provides principles, which guide the functioning of public administration. Among these principles public administration is required to promote development (RSA, 1996). In this regard, Ika (2012) argues that project management is "hailed as the promise for developing countries" and that organizations should rely on project management to achieve their development goals while managing objectives for long-term development results and tailoring project management to African cultures. With major political, economic and market reform, public institutions in South Africa have taken major strides to become globally 
competitive. As a result, these efforts have seen project management becoming instrumental in pursuit of development. In South Africa, projects are central in the delivery of developmental and strategic programmes. To this effect the post-apartheid Constitutional government set national targets for the delivery of infrastructure projects. During the State of the Nation address (SoNA) of 2003 then president Mr Mbeki remarked on the need for the Public Service to develop capacity for programme and project management and the importance of appointing dedicated and capable project managers. Similarly, the SoNA of 2012 by current president Mr Zuma remarks that the Presidential Infrastructure Coordination Commission (PICC) has identified and developed forty-three major projects and infrastructure initiatives from state-owned enterprises as well as national, provincial and local government departments. Significantly, infrastructure development has trickle-down economic effects. Samuel (2007) affirms that continued growth of any economy requires infrastructure development in order to meet the ever increasing socio-economic demands. Among major infrastructure development plans identified, transport and logistics projects are priority. Through these projects government seeks to enhance regional integration and trade relations (RSA, 2012). Technology advances through ICT or IT such as egovernment has a role to play in infrastructure development and service delivery.

Matavire et al., (2010) argue that governments across the globe have witnessed the widespread adoption of e-Government. E-Government represents a paradigm shift from traditional models of service delivery to more service-based models by governments. E-Government largely relies in the application of ICT. Borins as cited in Matavire et al., (2010) states that ICT has the following benefits:

- It reduces communication and information costs; and

- It maximizes the delivery speed.

Globally, lack of IT project skills remains a daunting challenge. This is confirmed by Standish Group, which is responsible for CHAOS University reports on IT project failures in the USA as indicated in Table 1. Simply put, ICT transforms government operations by making it more accessible, effective and accountable (Matavire et al, 2010:154). Hypothetically, e-Government has been adopted in Africa as a remedy for poverty related problems (Ochara cited in Matavire et al., 2010).

\begin{tabular}{|c|c|c|c|c|c|c|c|}
\hline $\begin{array}{l}\text { Project } \\
\text { Outcome }\end{array}$ & 1994 & 1996 & 1998 & 2000 & 2002 & 2004 & 2009 \\
\hline Succeeded & $16 \%$ & $27 \%$ & $26 \%$ & $28 \%$ & $34 \%$ & $29 \%$ & $32 \%$ \\
\hline Challenged & $53 \%$ & $33 \%$ & $46 \%$ & $49 \%$ & $51 \%$ & $53 \%$ & $44 \%$ \\
\hline Failed & $31 \%$ & $40 \%$ & $28 \%$ & $23 \%$ & $15 \%$ & $18 \%$ & $24 \%$ \\
\hline
\end{tabular}

Source: The Standish Group CHAOS Summary 2009

Table 1 indicates a decrease in project success rate in the USA. Only $32 \%$ of all projects succeeded and delivered on time and on budget in 2009. In the same year $44 \%$ were not completed on time and went over budget, $24 \%$ failed and terminated prior competition or delivered and never used. The South African government sees information society as a modernising catalyst in transforming the South African society and economy with ICT in delivery of projects. A similar challenge and trend noted in the US is likewise experienced in South Africa. In 2004 the failure rate of IT projects stood at 22\%. Furthermore, Van der Walt cited in Samuel (2007) provides an illustration of selected projected failures as indicated in Table 2.

Table 2: Selected project failures

\begin{tabular}{|c|c|c|c|}
\hline Project Location & Project Description & Failure & Causes \\
\hline Polokwane Prison & $\begin{array}{lrr}\text { Upgrading } & \text { of } & \text { Civil } \\
\text { Infrastructure, } & \text { Wet } & \text { Service \& } \\
\text { Fencing } & & \end{array}$ & $\begin{array}{l}\text { Project not completed on time and } \\
\text { within budget }\end{array}$ & $\begin{array}{l}\text { Poor time and } \\
\text { quality management }\end{array}$ \\
\hline $\begin{array}{l}\text { Helderstroom } \\
\text { Prison }\end{array}$ & $\begin{array}{l}\text { Upgrading water \& sewerage } \\
\text { works. }\end{array}$ & $\begin{array}{l}\text { Poor scope definition. } \\
\text { Contract documentation not aligned to } \\
\text { scope definition }\end{array}$ & $\begin{array}{l}\text { Poor scope } \\
\text { management }\end{array}$ \\
\hline $\begin{array}{l}\text { Baviaanspoort } \\
\text { Prison }\end{array}$ & $\begin{array}{l}\text { Repairs \& watering proofing to } \\
\text { roofing. }\end{array}$ & Project not completed on time. & $\begin{array}{l}\text { Poor project time } \\
\text { management. }\end{array}$ \\
\hline Pollsmor Prison & General upgrading of building & $\begin{array}{l}\text { Contractor over committed and } \\
\text { eventually liquidated }\end{array}$ & $\begin{array}{l}\text { Poor project cost } \\
\text { management. }\end{array}$ \\
\hline MakhadoAirforce & Construction of Taxiway & $\begin{array}{l}\text { Project not completed on time and cost } \\
\text { overrun. }\end{array}$ & $\begin{array}{l}\text { Poor project time } \\
\text { management. }\end{array}$ \\
\hline
\end{tabular}

Source: Adapted from Van der Walt cited in Samuel, 2007 
As indicated in Table 2 poor project cost, time, scope and quality management are the principal attributes to high rate of project failure in government. Ojiako (2012:1) argues that IT projects are often associated with high rate of desertion as a result of, among other things, complex technology and difficulties with the articulation of IT project implementation processes. Mahaney and Ledereras cited in Goldfinch (2000) point out that the bulk of research in IT regards project failure a norm and inevitable. Notwithstanding these project failures which fall into key project management knowledge areas which include scope, time, cost, quality, human resources, communication, risk and procurement management there are other complex causes of project failures that are worth noting. To maximise project success the integration of multidisciplinary project areas is pivotal (Project Management Institute (PMI), 2008).The review and analysis of the failures of the international development (ID) projects and project management problems in South Africa brings other daunting challenges into perspective as indicated in Table 2. As to project failures, Table 3 reflects three categories. Calderisias cited in Ika, (2012) contends that these are structural or contextual, institutional or sustainability, managerial or organizational problems which are the main culprits for project failure. Professionals should be capacitated in these three broad categories in order manage projects. The World Bank's contention and discovery is that administrative capacity is a major limitation in implementing projects.

Table 3: Project Management in South Africa

\begin{tabular}{|c|c|c|c|c|}
\hline $\begin{array}{l}\text { World Bank } \\
\text { Project }\end{array}$ & $\begin{array}{l}\text { Specific/Overall } \\
\text { objectives }\end{array}$ & $\begin{array}{l}\text { Structural/Contextual } \\
\text { Problems }\end{array}$ & $\begin{array}{l}\text { Institutional/Sustainability } \\
\text { Problems }\end{array}$ & $\begin{array}{l}\text { Managerial/ } \\
\text { Organizational } \\
\text { Problems }\end{array}$ \\
\hline \multirow[t]{2}{*}{$\begin{array}{l}\text { The South } \\
\text { Africa } \\
\text { Medupi Coal } \\
\text { plant (US\$3 } \\
\text { billion) }\end{array}$} & $\begin{array}{l}\text { Construction of a } \\
4,800-\mathrm{MW} \text { coal } \\
\text { power plant }\end{array}$ & $\begin{array}{l}\text { The electricity demand } \\
\text { for electricity in South } \\
\text { Africa far exceeds the } \\
\text { supply capacity thus }\end{array}$ & $\begin{array}{l}\text { Asymmetry of power between } \\
\text { project } \\
\text { planners/implementers and } \\
\text { beneficiaries }\end{array}$ & $\begin{array}{l}\text { No consideration } \\
\text { and involvement of } \\
\text { beneficiaries in } \\
\text { project processes }\end{array}$ \\
\hline & $\begin{array}{l}\text { and increase } \\
\text { electricity access } \\
\text { to the poor }\end{array}$ & $\begin{array}{l}\text { shortages and outages } \\
\text { since } 2008 \text {. }\end{array}$ & $\begin{array}{l}\text { The project largely benefits } \\
\text { major industries that } \\
\text { consume electricity below } \\
\text { cost rather than the poor who } \\
\text { suffer the negative } \\
\text { environmental impacts of the } \\
\text { project. }\end{array}$ & $\begin{array}{l}\text { Poor consideration } \\
\text { of health, water } \\
\text { scarcity, and } \\
\text { pressures on local } \\
\text { services at the } \\
\text { project design phase }\end{array}$ \\
\hline
\end{tabular}

Source: Calderisias cited in Ika, 2012

Evidence from South Africa indicates that the public sector has capacity constraints including scarce skills in critical thinking and knowledge management to effectively oversee and ensure the delivery of infrastructure in terms of, for instance, cost, quality and time. The need to enhance skills and capacity development in each of the project management knowledge areas is pivotal. At an institutional level, for example, project professionals make informed decisions on issues around sustainability and power relations before a project is being implemented which require certain skill sets. The global competitive index (GCI), 2012-2013confirms the need for requisite skills. When South Africa is compared to a few counterparts. While the quality of South Africa's electricity supply and quality of overall infrastructure are higher than Namibia and Morocco, these aspects are far below the rank as shown in as shown in Table 4.

Table 4: The quality of infrastructure in South Africa compared to Morocco and Nambia

\begin{tabular}{llll}
\hline Indicator & Rank/144 & Morocco & South Africa \\
\hline Namibia & 40 & 52 & 58 \\
Quality of overall infrastructure & 35 & 70 & 42 \\
Quality of raails & 39 & 49 & 46 \\
Quality of port infrastructure & 27 & 51 & 52 \\
Quality of air transport infrastructure & 59 & 52 & 15 \\
Quality of electricity supply & 52 & & 94 \\
\hline
\end{tabular}

Source: World Economic Forum, 2012

The world ranking suggests that project management skills remain a challenge. Withstanding these rankings and arising from this challenge is whether higher education institutions (HEIs) have the ability to produce well suited project management graduates to meet the demands of $21^{\text {st }}$ century infrastructure development. Among several problematic factors affecting efficiency in doing business in South Africa, the 
lack of an adequate educated workforce is rated high. Of 144 countries in the world South Africa's overall tertiary education enrolment is ranked 101 while the quality of education and math and science as key disciplines for development is 140 and 143 respectively (World Economic Forum, 2012). These rankings attest to South Africa's lack of adequate skills required by the labour market. This article therefore submits that building project management knowledge is a critical element in sustaining the required administrative capacity for infrastructure development in the $21^{\text {st }}$ century. As Garelick $(2012$, p. 1) is quoted at the outset, "traditional/skills-based teaching doesn't meet the demands of our $21^{\text {st }}$ century". Gehringas cited in Hans and Rwelamila (2012:456) argues that project success requires both project management competence and organizational project maturity and capability. Easterly as cited Ika (2012, p. 35) contends that without the required project knowledge "Big plans will always fail to reach the beautiful goals". With emphasis on infrastructure development in South Africa, higher education institutions (HEIs) have a role to play in supplying project management professionals to make service delivery promise a reality.

\section{Conclusion and Recommendations}

From a demand perspective, the National Research Foundation, Vision 2015 affirms the need for human capital development that contributes to a vibrant national innovation system (National Research Foundation, 2008). Thus, the development of the $21^{\text {st }}$ century project skills through PjBL is critical for the development and management project in the public sector. Post 1994 public sector reform initiatives in South Africa saw the adoption of New Public Management (NPM) principles including efficiency and effectiveness. South Africa's Constitution of 1996 highlights the significance of efficiency and efficiency in the delivery of public services including the delivery of the infrastructure projects. The implementation of these principles require project managers and administrators, as change agents, to be able to analyse all facets of change including decisions on the required projects to facilitate and expedite social and economic change. The critical factor to this process is for project managers and administration to acquire and develop the required skills. From a pedagogical perspective, HEIs in South Africa need to rethink curricula design and implementation. The complexity of public projects requires the development of $21^{\text {st }}$ century skills among managers in order to meet contemporary project demands. From a social constructivist stance, public administration and management, engineering and ICT disciplines in HEIs in South Africa are among the major disciplines central to project management. As such these disciplines will be the focal point of a research agenda that empirically tests the extent to which certain HEIs use PjBL pedagogy on the one hand. On the other hand, the research agenda includes investigating the extent to which public service officials require employees with PjBL generated skill sets for participation in a knowledge-based economy and information society in a global era.

\section{References}

Baron, B. \& Darling-Hammaond, L. (2008). Teaching for meaningful learning: A Review research on inquiry-based and cooperative learning. Retrieved from http://www.edutopia.org/pdfs/edutopia-teaching-for-meaningful-learning.pdf

Altbach, P. G. \& Knight, J. (2007) The Internationalisation of higher education: Motives and realities. Journal of Studies in International Education, 11(2).

Bell, S. (2010). Project-based learning for the $21^{\text {st }}$ century: skills for the future. The Clearing House, 83, 39 $-43$.

Blumefeld, P. C., Soloway, E., Marx, R. W., Krajcik, J. S., Guzdial, M. \& Palincsar, A. (1991). Motivating Project-based learning: Sustaining the doing, supporting the learning. Education Psychologist, 26, 369 - 398.

Boondee, V., Kidrakarn, P. \& Sa-Ngiamvibool, W. (2011). A Learning and teaching model using projectbased learning (PBL) on the web to promote cooperative learning. European Journal of Social Science, 21(3), 498 - 506.

Bottery, M. (2006). Education and globalisation: Redefining the role of the education professionals. Education review, 58, 95 - 113.

Dabbagh, N. (2003). Constructivism and its implication for teaching and learning.CLE Project Paper. Retrieved from classwell.gmu.edu.

Frank, M., Lavy, I. \& Elata, D. (2003). Implementing the project-based learning in an academic engineering course. International Journal of Technology and Design Education, 13, 273 - 88.

Gülbahar, Y. \& Tinmaz, H. (2006) Implementing project-based learning and e-portfolio assessment in an undergraduate course. Journal of Research on Technology in Education, 38(3), 309 - 327. 
Goldfinch, S. (2007).Pessimism, computer failure, and information systems development in the public sector. Public Administration Review, 67(5), 917 - 929.

Hans, R. T. \& Rwelamila, P. M. D. (2012).Knowledge base of project management in the South African ICT sector. Retrieved from http://airccj.org/CSCP/vol2/csit2141.pdf

Ika, L. A. (2012). Project management for development in Africa: Why projects are failing and what can be done about it? Project Management Journal, 43(4), 27-41.

Kars, S. (2009). The innovation experience: towards an organizational learning perspective of innovation. Retrieved from http://www.feweb.vu.nl/olkc2009/Papers/4BSelenKars.pdf

Kemp, S. (n.d). Constructivism and problem based learning. Retrieved from http://www.tp.edu.sg/pbl_sandra_joy_kemp.pdf

Langhorn, R. (2001). The coming of globalisation: Its evolution and contemporary consequences. New York: Palgrave.

Matavire, R., Chigona, W., Roode, D. \& Sewchurran, E. (2010). Challenges of eGovernment project implementation in a South African context. The Electronic Journal of Information Systems Evaluation, 13(2), 153 - 164.

National Research Foundation (NRF). (2008). Strategic plan of the National Research Foundation. Retrieved from http://www.nrf.ac.za/files/file/nrf_vision_2015.pdf

Okoli, N. J. (2012). Effects of globalisation on education in Africa. Academic research international, 2(3), $656-164$.

Ojiako, U. (2012). A Management perspective on the failure of IS\&T Projects. International Journal of Information Project Management, 3(3), 1 - 13.

Paavola, S. \& Hakkarainen, K. (2005).The Knowledge creation metaphor - An emergent epistemological approach to learning. Science and Education, 14, 535-557.

Panasan, M. \& Naungchalerm, P. (2010).Learning outcome of project-based and inquiry-based learning activities. Journal of Social Sciences, 6(2) $252-255$.

Project Management Institute (PMI). (2008). Project management knowledge areas. Retrieved from www.pmi.org/pmief/.../Lesson_1-Nine_Knowledge_Area_Defintions.pdf

Prince, M.J. \& Felder, R. M. (2006). Inductive teaching and learning methods: Definitions, comparisons and research bases. J. Engr. Education, 95(2), 123 - 138.

Reynolds, R. (2009). The emergence of six contemporary learning abilities (6-CLAs) in middle school, high school and community colleges students as they design web-games and use project-based social media in globaloria. Retrieved fromhttp://www.worldwideworkshop.org/pdfs/GlobaloriaEmergencofSixCLAs.pdf

Republic of South Africa. (1996). The Constitution of the Republic of South Africa, 1996. Pretoria: Government Printer.

Republic of South Africa. (2012). State of the Nations Address (SONA). Retrieved from http://www.info.gov.za/speech/DynamicAction?pageid=461\&tid=55960

Republic of South Africa. (2012). State of the Nations Address (SONA). Retrieved from http://www.info.gov.za/speech/DynamicAction?pageid=461\&tid=55960

Samuel, R. (2007). Effective and efficient project management on government projects. Retrieved from http://www.cib2007.com/papers/CIDB2008\%20Final\%20paper\%20No\%2021.pdf

The Standish Group CHAOS. (2009). The USA Standish findings by year. Updated for 2009 report. Retrievedfromhttp://www.portal.state.pa.us/portal/server.pt/document/standish_group_chaos _summary_2009_pdf

Thomas, J. W. (2000). A Review of research on project-based learning. Retrieved from http://www.ri.net/middletown/mef/linksresources/documents/researchreviewPBL_070226.pd

Vagelatos, A., Tsaknakis, H., Foskolos, F. \& Komninos, T. (2010).Outsourcing project management services in the public sector. International Journal of Digital Society, 1(1).

World Economic Forum. (2012). The global competitive report 2012-2013. Retrieved from http://www3.weforum.org/docs/WEF_GlobalCompetitivenessReport_2012-13.pdf

Woodhall, M. (1997). The reform of higher education in developing countries: Some implementation issues. Prepared for higher development weeks. World Bank. Washington, DC. 